4. Bando K, Kobayashi J, Kosakai Y, Hirata M, Sasako Y, Nakatani S, et al. Impact of Cox maze procedure on outcome in patients with atrial fibrillation and mitral valve disease. J Thorac Cardiovasc Surg. 2002;124:575-83.

5. Fukada J, Morishita K, Komatsu K, Sato H, Shiiku C, Muraki S, et al. Is atrial fibrillation resulting from rheumatic mitral valve disease a proper indication for the maze procedure? Ann Thorac Surg. 1998;65:1566-70.

6. Izumoto H, Kawazoe K, Kitahara H, Kamata J. Operative results after the Cox/ maze procedure combined with a mitral valve operation. Ann Thorac Surg. 1998;66:800-4

7. Lee JW, Choo SJ, Kim KI, Song JK, Kang DH, Song JM, et al. Atrial fibrillation surgery simplified with cryoablation to improve left atrial function. Ann Thorac Surg. 2001;72:1479-83.

8. Deneke T, Khargi K, Grewe PH, Laczkovics A, von Dryander S, Lawo T, et al. Efficacy of an additional MAZE procedure using cooled-tip radiofrequency ablation in patients with chronic atrial fibrillation and mitral valve disease. A randomized, prospective trial. Eur Heart J. 2002;23:558-66

9. Handa N, Schaff HV, Morris JJ, Anderson BJ, Kopecky SL, EnriquezSarano M. Outcome of valve repair and the Cox maze procedure for mitral regurgitation and associated atrial fibrillation. J Thorac Cardiovasc Surg. 1999; 118:628-35.

10. Jatene MB, Marcial MB, Tarasoutchi F, Cardoso RA, Pomerantzeff P, Jatene AD. Influence of the maze procedure on the treatment of rheumatic atrial fibrillationevaluation of rhythm control and clinical outcome in a comparative study. Eur J Cardiothorac Surg. 2000;17:117-24

11. Raanani E, Albage A, David TE, Yau TM, Armstrong S. The efficacy of the Cox/ maze procedure combined with mitral valve surgery: a matched control study. Eur J Cardiothorac Surg. 2001;19:438-42.

12. Fiore AC, Barner HB, Swartz MT, McBride LR, Labovitz AJ, Vaca KJ, et al. Mitral valve replacement: randomized trial of St. Jude and Medtronic Hall prostheses. Ann Thorac Surg. 1998;66:707-13.

13. Hammermeister KE, Sethi GK, Henderson WG, Oprian C, Kim T, Rahimtoola S. A comparison of outcomes in men 11 years after heart-valve replacement with a mechanical valve or bioprosthesis. Veterans Affairs Cooperative Study on Valvular Heart Disease. N Engl J Med. 1993;328:1289-96.
14. Turpie AG, Gent M, Laupacis A, Latour Y, Gunstensen J, Basile F, et al. A comparison of aspirin with placebo in patients treated with warfarin after heart-valve replacement. N Engl J Med. 1993;329:524-9.

15. Gillinov AM, Sirak J, Blackstone EH, McCarthy PM, Rajeswaran J, Pettersson G, et al. The Cox maze procedure in mitral valve disease: predictors of recurrent atrial fibrillation. $J$ Thorac Cardiovasc Surg. 2005;130:1653-60.

16. Izumoto H, Kawazoe K, Eishi K, Kamata J. Medium-term results after the modified Cox/Maze procedure combined with other cardiac surgery. Eur J Cardiothorac Surg. 2000;17:25-9.

17. Kamata J, Kawazoe K, Izumoto H, Kitahara H, Shiina Y, Sato Y, et al. Predictors of sinus rhythm restoration after Cox maze procedure concomitant with other cardiac operations. Ann Thorac Surg. 1997;64:394-8.

18. Choo SJ, Park NH, Lee SK, Kim JW, Song JK, Song H, et al. Excellent results for atrial fibrillation surgery in the presence of giant left atrium and mitral valve disease. Eur J Cardiothorac Surg. 2004;26:336-41.

19. Henry WL, Morganroth J, Pearlman AS, Clark CE, Redwood DR, Itscoitz SB et al. Relation between echocardiographically determined left atrial size and atrial fibrillation. Circulation. 1976;53:273-9.

20. Bailey GW, Braniff BA, Hancock EW, Cohn KE. Relation of left atrial pathology to atrial fibrillation in mitral valvular disease. Ann Intern Med. 1968;69:13-20.

21. Davies MJ, Pomerance A. Pathology of atrial fibrillation in man. Br Heart J. 1972; 34:520-5.

22. Lee JW, Park NH, Choo SJ, Jo MS, Song H, Song MG. Surgical outcome of the maze procedure for atrial fibrillation in mitral valve disease: rheumatic versus degenerative. Ann Thorac Surg. 2003;75:57-61.

23. Yuda S, Nakatani S, Kosakai Y, Satoh T, Goto Y, Yamagishi M, et al. Mechanism of improvement in exercise capacity after the maze procedure combined with mitral valve surgery. Heart. 2004;90:64-9.

24. Marui A, Saji Y, Nishina T, Tadamura E, Kanao S, Shimamoto T, et al. Impact of left atrial volume reduction concomitant with atrial fibrillation surgery on left atrial geometry and mechanical function. J Thorac Cardiovasc Surg. 2008;135:1297-305.

25. Yuda S, Nakatani S, Kosakai Y, Yamagishi M, Miyatake K. Long-term follow-up of atrial contraction after the maze procedure in patients with mitral valve disease. J Am Coll Cardiol. 2001;37:1622-7.

\title{
COMMENTARY
}

\section{The quest to identify predictors for success and failure after the Cox-Maze procedure for the treatment of atrial fibrillation}

\author{
Niv Ad, MD
}

In this issue of the Journal, Dr Joon Bum Kim and colleagues $^{1}$ present their experience with more than 400 patients who underwent the modified Cox-Maze III procedure combined with mitral valve surgery. This is a retrospective study designed to answer the interesting question of

From the Inova Heart and Vascular Institute, Falls Church, Va.

Received for publication July 12, 2009; accepted for publication July 21, 2009.

Address for reprints: Niv Ad, MD, Inova Heart and Vascular Institute, 3300 Gallows

Rd, Falls Church, VA 22042 (E-mail: nivadmd@hotmail.com).

J Thorac Cardiovasc Surg 2010;139:117-8

$0022-5223 / \$ 36.00$

Copyright $(c) 2010$ by The American Association for Thoracic Surgery

doi:10.1016/j.jtcvs.2009.07.054 whether the type of mitral valve surgery performed has any impact on the success rate of the surgical ablation.

This is a relatively large report to include 435 patients (226 patients in the repair group). The main conclusion of this study is that the success rate in ablation atrial fibrillation was not affected by the type of the mitral valve surgery (repair or replacement); however, left atrial transport was documented to be superior in the repair group. The predictors for failure that were recognized in the study were the preoperative age, fine atrial fibrillation wave pattern, and left atrial size more than $6 \mathrm{~cm}$ preoperatively.

The authors of this article are to be congratulated for their excellent results in a large series of patients. Nevertheless, 
the current report brings attention to some of the difficulties and challenges that are currently experienced when assessing the results of surgical treatment of atrial fibrillation and its impact on patient outcomes. The majority of the publications in this field are retrospective, the surgical techniques vary, and the outcome is not simple because patients do cross from success to failure along the followup period. The primary goal of this study as presented was to test whether the type of mitral valve surgery could affect the success rate of the surgical ablation. As mentioned, this is a unique research question; however, can we really expect a valid answer in a retrospectively designed study?

Several risk factors for late failure of the Cox-Maze procedure were described in the literature, and the type of mitral valve surgery applied is not one of them. Variables such as age, duration of atrial fibrillation, and left atrial size are the most consistently discussed predictors for failure. ${ }^{2}$ Variables such as the type of atrial fibrillation and the type of the modification to the Cox-Maze procedure or lesion set have been identified as predictors for failure but less consistently. ${ }^{3}$

In this work, as in many other studies, we assume that the operative technique in use to address atrial fibrillation is uniform across the series, and as a result we focus our analysis on the clinical variables. However, in this study there are 3 major variables that may have a major impact on the results:

1. The left atrial size was addressed in some patients with an attempt to reduce it to less than $5 \mathrm{~cm}$.

2. The energy source to supplement the surgical incisions was either cryothermal or microwave.

3. The ablation was applied without clear definition regarding the duration and ablation end points.

These variations in the operative technique can be controlled only in a prospective study for which clear pre-study definitions mandate the surgical approach. The use of 2 different energy sources may be problematic if done in an uncontrolled study. In this study, microwave energy was applied for 1 to 2 minutes, with no definite end points and thus room for significant variability. As is well known, the microwave technology was discontinued by the company because of alarming reports of low efficacy. On the other hand, the other energy source in use in this series was cryothermal, which in my opinion is the most reliable ablation tool when applied on an arrested heart with definite visual end points to assess transmurality. The other important variable is related to left atrial reduction. Although, I agree with the authors that left atrial reduction may be indicated in a pa- tient with a large atrium, it may suggest lack of uniformity because it was done by different surgeons over a period of 8 years with the potential of variation that in turn may affect the results. This potential limitation also may be evident by identifying left atrial size as a predictor to failure when in fact it was addressed when necessary in all patients.

I would like to commend the authors' high rate of followup using electrocardiography and 24-hour Holter monitoring; it is unique and a true strength of the study that provides us with valuable evidence. The data presented to us suggest a relatively high success rate in ablating atrial fibrillation in a group of patients with a large left atrium (an average size $>6 \mathrm{~cm}$ ) and a high incidence of rheumatic heart disease. As in other reports, the thromboembolic event rate was low ${ }^{4}$ in a high-risk group of patients. Atrial transport was found to be better in the mitral valve repair group; however, I agree with the authors that this may be related to the abundance of patients with rheumatic heart disease in the mitral valve replacement group.

The Cox-Maze procedure was first performed more than 20 years ago, and its basic concept is well accepted although often being modified. In general, the patients who are present for surgical ablation of atrial fibrillation pose a special challenge, because the arrhythmias are usually accompanied with an enlarged left atrium and advanced tissue remodeling. It is important for us to further adopt the recommendations suggested by the different societies and associations with regard to follow-up and method of reporting. However, more important, we need to task ourselves and perform randomized controlled studies designed to answer important questions related to lesion pattern, compare the different energy sources, and assess the necessity of left atrial reduction procedures and the impact of anticoagulation treatment. Such studies will elevate the level of evidence of the reports dealing with the surgical treatment of atrial fibrillation.

\section{References}

1. Kim JB, Yun TJ, Chung CH, Choo SJ, Song H, Lee JW. Long-term outcome of modified maze procedure combined with mitral valve surgery: analysis of outcomes according to the type of mitral valve surgery. $J$ Thorac Cardiovasc Surg. 2010;139:111-7.

2. Ad N. The Cox-Maze procedure: history, results, and predictors for failure. J Interv Card Electrophysiol. 2007;20:65-71.

3. Gillinov AM, Sirak J, Blackstone EH, McCarthy PM, Rajeswaran J, Pettersson G, et al. The Cox-Maze procedure in mitral valve disease: predictors of recurrent atrial fibrillation. J Thorac Cardiovasc Surg. 2005;130:1653-60.

4. Bando K, Kobayashi J, Hirata M, Satoh T, Niwaya K, Tagusai O, et al. Early and late stroke after mitral valve replacement with mechanical prosthesis: risk factor analysis of a 24 years experience. J Thorac Cardiovasc Surg. 2003;126:358-64. 